\title{
STUDY OF SOCIOECONOMIC IMPACT AFTER ONE YEAR OF ANTIRETROVIRAL THERAPY IN HIV INFECTED PATIENTS IN A TERTIARY CARE CENTRE IN NORTH BENGAL
}

\author{
Bapi Lal Bala1, Biswadev Basu Majumdar², Apu Adhikary33, Swati Pal', Jyotirmoy Pal5, Saikat Datta6, Achintya Narayan Ray ${ }^{7}$, \\ Debasis Chakrabarti ${ }^{8}$
}

${ }^{1}$ Assistant Professor, Department of Medicine, NBMCH.

${ }^{2}$ Senior Resident, Department of Cardiology, $\mathrm{NBMCH}$.

${ }^{3}$ RMO Cum Clinical Tutor, Department of Medicine, NBMCH.

${ }^{4}$ Assistant Professor, Department of Economics, Kidderpore College, Kolkata.

${ }^{5}$ Professor, Department of Medicine, RG Kar Medical College, Kolkata..

${ }^{6}$ Associate Professor, Department of Medicine, NBMCH.

${ }^{7}$ Associate Professor, Department of Medicine, NBMCH.

${ }^{8}$ Associate Professor, Department of Medicine, NBMCH.

\section{ABSTRACT}

\section{BACKGROUND}

Although data regarding socioeconomic impact post-ART is available in India, the educational aspect has not been well studied. In this article, we studied overall impact of ART in newly diagnosed HIV patients with reference to monthly income, number of working days and school dropout and literacy rate on a short-term basis in a tertiary care centre in North Bengal.

\section{MATERIALS AND METHODS}

It is an observational study. One hundred and twenty patients were followed for one year after initiating ART. Data Collection and Categorisation were done according to the statistical software application such as mean comparison, one way ANOVA, using the statistical software IBM-SPSS (ver.19. Chicago inc.) assuming the significance at 95\% of CI.

\section{RESULTS}

The school dropout rate at baseline was $22(32.8 \%)$ in 67 school children in the study. After 6 months, dropout rate was 13 cases $(19.4 \%)$ and after 12 months was only $4(6 \%)(\mathrm{p}<0.05)$. Working days in a month of 101 patients at baseline was $47(46.5 \%)$ cases in the $<10$ days category while $39(38.6 \%)$ cases were in $10-20$ days working category and $15(14.9 \%, \mathrm{n}=101)$ in the $>20$ days category. But after 6 months of ART, working capability of the study population increased so that $16(15.8 \%)$ cases had $<10$ days in a month, $54(53.5 \%)$ cases had $10-20$ days in a month, and rest (30.7\%) had > 20 working days in a month. After 12 months of ART, it further increased to $12(11.9 \%), 27(26.7 \%)$ and $62(61.4 \%)$ respectively ( $p<0.05)$. ART also increased the monthly income of 71 patients in study group so that after 6 months, people in low income category reduced from $30(40.25 \%)$ to $6(8.45 \%$,) while income in the high-income group increased from $7(9.85 \%)$ to $14(19.71 \%)(\mathrm{p}<0.05)$. ART improved overall socioeconomic outcome in patients with HIV/AIDS.

\section{CONCLUSION}

ART has significant socioeconomic outcome in patients receiving therapy and proper therapy improves the social and financial status of the patient uplifting his overall productivity in the society.

\section{KEYWORDS}

Antiretroviral Therapy, Socioeconomic Outcome.

HOW TO CITE THIS ARTICLE: Bala BL, Majumdar BB, Adhikary A, et al. Study of socioeconomic impact after one year of antiretroviral therapy in HIV infected patients in a tertiary care centre in North Bengal. J. Evolution Med. Dent. Sci. 2017;6(86): 5930-5933, DOI: $10.14260 /$ jemds/2017/1290

\section{BACKGROUND}

The HIV epidemic causes adverse health, social and economic impacts on the family. As HIV mostly occurs among the reproductive age group, the decreased productivity and the cost of care severely affect the economy. Cost of therapy for the patient is also very high.

'Financial or Other Competing Interest': None.

Submission 05-09-2017, Peer Review 12-10-2017,

Acceptance 19-10-2017, Published 26-10-2017.

Corresponding Author:

Dr. Biswadev Basu Majumdar,

C/o. Bijan Basu Majumdar,

Sevagram, P. O. Debnagar,

Jalpaiguri-735102,

West Bengal

E-mail: dr.biswadev.basu@gmail.com

DOI: $10.14260 /$ jemds $/ 2017 / 1290$
Family of the infected persons faces severe economic crisis and frequently lose jobs that affect not only the persons, but also adversely affect their family including children. There has been an adverse emotional and psychological effect on the family, particularly widows and orphans. Stigmatisation and discrimination against the infected persons and their family members have worsened the situation further.[1] In this study, we followed up the patients who were getting ART in our ART centre, in respect to the socioeconomical impact of successful antiretroviral therapy (ART) in a developing country like India.

\section{MATERIALS AND METHODS}

This study was conducted at the ART centre of North Bengal Medical College under the Department of General Medicine. HIV/AIDS patients attending Medical Outpatient Department (MOPD) or ART Centre of North Bengal Medical College and Hospital were selected for study. 


\section{Study Design}

It is an observational study.

\section{Inclusion Criteria}

1. ART naïve HIV positive patients greater than 12 years.

2. First line drug regime approved by NACO.

\section{Exclusion Criteria}

1. Patients with poor adherence.

2. Pre-existing IHD, DM, IGT, Dyslipidaemia at initiation.

NACO guidelines for eligibility criteria of ART therapy were maintained. Patients were selected from the ART register who were started on ART. Newly registered patients from January 2010 to January 2011 were taken and each patient was followed up for 1 year for incidences of specific OIs at baseline, 6 months and at 12 months. At the beginning of ART therapy, questionnaires were put up for all candidates of our study regarding four issues - (a) employment (b) monthly income, (c) no. of days of absence from job, (d) education of their children (regarding dropouts). Same interview was repeated six monthly and observed whether there are any changes in those parameters.

\section{Statistical Methods}

Data were collected, assembled and transferred to Excel Spread sheet (MS Excel 2007) and analysed using IBM-SPSS ver. 16, Chicago. Pearson's Chi Square Test was used. All the statistical significance tests were done assuming Level of Significance at $95 \%$ confidence intervals.

\section{RESULTS}

Here, 120 diagnosed cases of HIV-infected patients, who attended the ART Centre of North Bengal Medical College and Hospital for ART were selected for study. Relevant history taking, clinical examination and investigations for OIs were done at the baseline after $6 \& 12$ months. Follow-up data were available for 101 patients at 6 months and 12 months (10 patients died, 5 patients were lost to follow-up and 5 were transferred out to the other ART centre). Data from patients, who died, were lost to follow-up or transferred out to the other ART centre were not included in this analysis. Patients of age group 18 onwards were included with maximum patients being in 30-39 years age group.

\section{Analysis of Data was done which revealed the following} Social Implications of ART:

1. Percentage of school dropout of children of the study population was decreasing following Antiretroviral Therapy (ART).

2. After 6 months and 12 months of Antiretroviral therapy (ART), monthly income of the study population was significantly increased.

3. Working ability of the study population was also increasing with receiving of HAART. The present study indicated that individuals were able to gain considerable benefits from HAART and were able to resume economic activity.

\begin{tabular}{|c|c|c|c|c|}
\hline $\begin{array}{c}\text { Age } \\
\text { (Mean } \pm \text { SD) }\end{array}$ & \multicolumn{4}{|c|}{$33.20 \pm 7.625$} \\
\hline $\begin{array}{c}\text { Gender } \\
\text { (M: F= 1.59) }\end{array}$ & \multicolumn{2}{|c|}{ Male: 62 (61.4\%) } & Female: 39 (38.6\%) \\
\hline Religion & $\begin{array}{c}\text { Hindu 74 } \\
(73.3 \%)\end{array}$ & $\begin{array}{c}\text { Muslim } 16 \\
(15.8 \%)\end{array}$ & $\begin{array}{c}\text { Buddhists } \\
9(8.9 \%)\end{array}$ & $\begin{array}{c}\text { Christian } \\
2(2 \%)\end{array}$ \\
\hline $\begin{array}{c}\text { Marital } \\
\text { status }\end{array}$ & $\begin{array}{c}\text { Married 70 } \\
(69.3 \%)\end{array}$ & $\begin{array}{c}\text { Single } 15 \\
(14.9 \%)\end{array}$ & $\begin{array}{c}\text { Widow } 9 \\
(8.9 \%)\end{array}$ & $\begin{array}{l}\text { Divorcee } \\
(6.9 \%)\end{array}$ \\
\hline \multicolumn{4}{|c|}{ Table 1. Baseline Characteristics of Population } \\
\hline
\end{tabular}

The table shows that, out of 101 cases, 62 were male patients $(61.4 \%, \mathrm{n}=101)$ and 39 were female patients $(38.6 \%, \mathrm{n}=101)$. So the Male: Female ratio is 1.59: 1 . The table also shows that, out of 101 cases, 74 patients were of Hindu religion (73.3\%), 16 patients were of Muslim religion (15.8\%), 9 patients were of Buddhist religion (8.9\%) and 2 patients were of Christian (2.0\%). So the Hindu: Muslim: Buddhist: Christian ratio is 7.3: 1.58: 0.89: 0.23. We also see that, out of 101 cases, 15 (14.85\%) patients were single, 70 $(69.30 \%)$ patients were married, 9 (8.91\%) patients were widowed and 7 (6.93\%) patients were divorced. These were the baseline features of the subjects taken in the study.

\begin{tabular}{|c|c|c|c|}
\hline $\begin{array}{c}\text { Educational } \\
\text { Status }\end{array}$ & Male & Female & Total \\
\hline Illiterate & $10(16.12 \%)$ & $17(43.58 \%)$ & $27(26.73 \%)$ \\
\hline Primary School & $26(41.93 \%)$ & $10(25.64 \%)$ & $36(35.64 \%)$ \\
\hline High School & $24(38.70 \%)$ & $10(25.64 \%)$ & $34(33.66 \%)$ \\
\hline $\begin{array}{c}\text { College and } \\
\text { above }\end{array}$ & $2(3.22 \%)$ & $2(5.12 \%)$ & $4(3.96 \%)$ \\
\hline \multicolumn{3}{|c|}{$\begin{array}{c}\text { Table 2. Educational Status and Sex Wise } \\
\text { Distribution of Patients in the Study Population }\end{array}$} \\
\hline
\end{tabular}

Out of the 101 cases, educational status in females $(n=39)$ was as follows: Illiterates (43.58\%) were high followed by "up to primary school" (25.64\%), high school (25.64\%) and college and above (5.12\%). In males $(n=62)$ : Illiterates were at $16.12 \%$, followed by primary school $(41.93 \%)$, High school (38.70\%), and College and above (3.22\%).

\begin{tabular}{|c|c|c|c|c|}
$\begin{array}{c}\text { School } \\
\text { Dropout }\end{array}$ & At Baseline & $\begin{array}{c}\text { After 6 } \\
\text { Months }\end{array}$ & $\begin{array}{c}\text { After 12 } \\
\text { Months }\end{array}$ & Significance \\
\hline Yes & $22(32.8 \%)$ & $\begin{array}{c}13 \\
(19.4 \%)\end{array}$ & $4(6 \%)$ & $\begin{array}{c}\mathrm{X}^{2} \text { for linear } \\
\text { trend }=15.305 \\
\mathrm{p}<0.05 \\
(0.00009)\end{array}$ \\
\hline No & $45(67.2 \%)$ & $\begin{array}{c}54 \\
(80.6 \%)\end{array}$ & $63(94 \%)$ & $\begin{array}{c}\text { Table 3. Summary of School Dropout of } \\
\text { Children of the Study Population (n= 67) }\end{array}$ \\
\hline
\end{tabular}

Out of the 101 study population, 67 cases had school going children. At the baseline, $22(32.8 \%, n=67)$ of study population had history of "school dropout" in their children. After 6 months and 12 months of highly active antiretroviral therapy (HAART), school dropout of children of the study population decreased significantly. After 6 months, there were 12 cases $(17.9 \%, \mathrm{n}=67)$ and after 12 months there were only $4(6 \%, n=67)$. These changes were statistically significant $(\mathrm{p}<0.05)$. 


\begin{tabular}{|c|c|c|c|c|}
\hline $\begin{array}{c}\text { Monthly } \\
\text { Income (Rs) }\end{array}$ & Baseline & 6 Months & 12 Months & Significance \\
\hline$<1000$ & $\begin{array}{c}30 \\
(40.25 \%)\end{array}$ & $\begin{array}{c}6 \\
(8.45 \%)\end{array}$ & $\begin{array}{c}6 \\
(8.45 \%)\end{array}$ & \multirow{4}{*}{$\begin{array}{c}\text { Pearson } \\
\text { Chi-square } \\
41.7 \\
\text { P }<0.05 \\
(0.000)\end{array}$} \\
\hline $1000-2000$ & $\begin{array}{c}22 \\
(30.98 \%)\end{array}$ & $\begin{array}{c}25 \\
(35.21 \%) \\
\end{array}$ & $\begin{array}{c}18 \\
(25.35 \%)\end{array}$ & \\
\hline 2001- 5000 & $\begin{array}{c}12 \\
(16.90 \%) \\
\end{array}$ & $\begin{array}{c}31 \\
(43.66 \%)\end{array}$ & $\begin{array}{c}33 \\
(46.47 \%)\end{array}$ & \\
\hline$>5000$ & $\begin{array}{c}7 \\
(9.85 \%)\end{array}$ & $\begin{array}{c}9 \\
(12.67 \%)\end{array}$ & $\begin{array}{c}14 \\
(19.71 \%)\end{array}$ & \\
\hline & & & & \\
\hline
\end{tabular}

Out of the 101 study population, 30 cases were housewives and 71 cases were earners from different occupations. They were categorised depending on their monthly income as $<1000$ Rs., 1000 to 2000 Rs., 2001 to 5000 Rs., and $>5000$ Rs. At the baseline of the study, 30 (40.25\%, n = 71) cases had monthly income $<1000$ Rs., 22 (30.98\%, $\mathrm{n}=$ 71) cases had monthly income 1000 to 2000 Rs., 12 (16.90\%, $\mathrm{n}=71$ ) cases had monthly income 2001 to 5000 Rs. and 7 $(9.85 \%, n=71)$ cases had monthly income > Rs. 5000 . After 6 months and 12 months of highly active antiretroviral therapy (HAART), monthly income of the study population was significantly increased. After 6 months of HAART, 6 (8.45\%, n = 71) cases had monthly income $<1000$ Rs., 25 (35.21\%, $\mathrm{n}=$ 71) cases had monthly income 1000 to 2000 Rs., 31 (43.66\%, $\mathrm{n}=71$ ) cases had monthly income 2001 to 5000 Rs., and 9 $(12.67 \%, \mathrm{n}=71)$ cases had monthly income $>5000 \mathrm{Rs}$. After 12 months of HAART, $6(8.45 \%, \mathrm{n}=71)$ cases had monthly income < 1000 Rs., $18(25.35 \%, \mathrm{n}=71)$ cases had monthly income 1000 to 2000 Rs., 33 (46.47\%, n = 71) cases had monthly income 2001 to 5000 Rs., and $14(19.71 \%, \mathrm{n}=71)$ cases had monthly income $>5000$ Rs. This change of monthly income of the study population was statistically significant $(\mathrm{p}<0.05)$

\begin{tabular}{|c|c|c|c|c|}
\hline $\begin{array}{c}\text { Working } \\
\text { Days per } \\
\text { Month }\end{array}$ & Baseline & 6 Months & $\begin{array}{c}12 \\
\text { Months }\end{array}$ & Significance \\
\hline$<10$ & $\begin{array}{c}47 \\
(46.5 \%)\end{array}$ & $16(15.8 \%)$ & $\begin{array}{c}12 \\
(11.9 \%)\end{array}$ & \multirow{3}{*}{$\begin{array}{c}\text { Pearson Chi- } \\
\text { square } 70.23 \\
\text { p }<0.05 \\
(0.000)\end{array}$} \\
\hline $10-20$ & $39(38.6)$ & $54(53.5 \%)$ & $\begin{array}{c}27 \\
(26.7 \%)\end{array}$ & \\
\hline$>20$ & 15 (14.9) & $31(30.7 \%)$ & $\begin{array}{c}62 \\
(61.4 \%)\end{array}$ & \\
\hline
\end{tabular}

Table 5. Changes in Working Ability in a Month $(n=101)$

The table shows that, the higher number of study population had less working capability at the beginning of the study. At the baseline, 47 (46.5\%) cases had $<10$ days working capability in a month. Out of the rest, 39 (38.6\%, n $=101$ ) cases had $10-20$ days working capability and 15 $(14.9 \%, \mathrm{n}=101)$ cases had $>20$ days working capability in a month. After 6 months and 12 months of HAART, working capability of the study population was increasing. 16 (15.8\%, $\mathrm{n}=101$ ) cases had $<10$ days working capability in a month, $54(53.5 \%, \mathrm{n}=101)$ cases had $10-20$ days' capability in a month, and rest $(30.7 \%, \mathrm{n}=101)$ had $>20$ days' capability in a month. After 12 months of HAART, $12(11.9 \%, \mathrm{n}=101)$ cases had $<10$ days' capability in a month, $27(26.7 \%, \mathrm{n}=$ 101) cases had 10 - 20 days' capability in a month, and 62 $(61.4 \%, \mathrm{n}=101)$ had $>20$ days' capability in a month. These changes of working capability of the study population were significant $(\mathrm{p}<0.05)$.

\section{DISCUSSION}

The mean age of the patients in this study was 33.15. HIV Sentinel surveillance and HIV Estimation, 2006 in India showed that $88.7 \%$ of HIV were in 15 - 49 years of age and a gender ratio of 1.56: 1 , which is almost equal in this study. The baseline total cholesterol, LDL-c and triglyceride levels were within normal range, whereas HDL-c level were almost in the lower range. Fasting Blood Glucose (FBG) level also was in the normal range at baseline. This study explores the short-term socioeconomic effect of Antiretroviral Treatment (ART) in HIV/AIDS patients as well as of the family and society. The socioeconomic impact of antiretroviral treatment on individuals in Soweto, South Africa explores the shortterm socioeconomic effect of antiretroviral treatment (ART) in HIV positive patients attending the perinatal HIV Research Unit clinics in Soweto. An overall increase in mean personal and household income following commencement of ART was noted. Mean personal income rose $53 \%$ over baseline income. A decrease in the number of meals missed in households was noted in $10 \%$ of the sample. The leading themes regarding income were change in employment status and social grants. Antiretroviral treatment increased the capacity to seek employment and unemployed individuals were actively searching for work. [2]

Numerous studies have been conducted to assess the socioeconomic impact of HIV/AIDS. Desmond et al (2000) argued that because HIV/AIDS causes significant increase in illness and death in prime age adults, the effect is seen in both households and communities. The documented economic impact at the household level is decreased income, increased costs, decreased productive capacity and changing expenditure patterns. The decrease in income, together with the increase in health care expenditure, leads to a fall in expenditure on other basic needs. This shrinkage and reallocation of the household budget reduces food security thereby increasing the chances of malnutrition and sickness in other member in the home.[2] Larson et al (2008) investigated the impact of ART on days harvesting tea per month for tea estate workers in Kenya. They found that the first year on treatment had a large, positive impact on the ability of workers to undertake their primary work activity. [2] $\mathrm{Xu}$ et al (2007) reported that in rural Eastern China, treatment costs consume a significant proportion of the family's income. Patients believe they cannot engage in hard labour, give up their existing jobs or have difficulty in finding jobs.[2] In a longitudinal, controlled study of households affected by HIV in the Free State, South Africa, Booysen et al (2002) found HIV affected households were poorer and more dependent on non-employment sources of income and spent less money on food.[2] Brown et al concluded that communication and explanation with people with HIV/AIDS seems the most promising approach, in combination with information about reducing stigmatisation. Policy making should be directed at laws that protect the human rights of HIV- infected people, regardless of their behaviour (such as drug use) or place of origin, so that acceptance, care and support increase for people and families affected by HIV.[3] So from all these studies and study result of this study it can be said that, the benefits of ART in HIV/AIDS patients have been 
well established in respect of increased incidence of personal as well as socioeconomic improvement and has a positive influence in patients' life.

\section{CONCLUSION}

Introduction of Antiretroviral Therapy (ART) has shown improvement although in a short time analysis, in both physical as well as the individual performance and overall socioeconomic development in patients with HIV/AIDS. This study is unique in the fact that it emphasises the schooling of children as an important marker of social development in contrast to other similar studies in India.

\section{REFERENCES}

[1] Narain JP, Lo YR. Epidemiology of HIV-TB in Asia. Indian J Med Res 2004;120(4):277-89.

[2] Chhagan V, Luiz J, Mohapi L, et al. The socioeconomic impact of antiretroviral treatment on individuals in Soweto, South Africa. Health Sociology Review 2008;17(1):95-105.

[3] Brown L, McIntyre K, Trujillo L. Interventions to reduce HIV/AIDS stigma: what have we learned? AIDS Educ Prev 2003;15(1):49-69. 